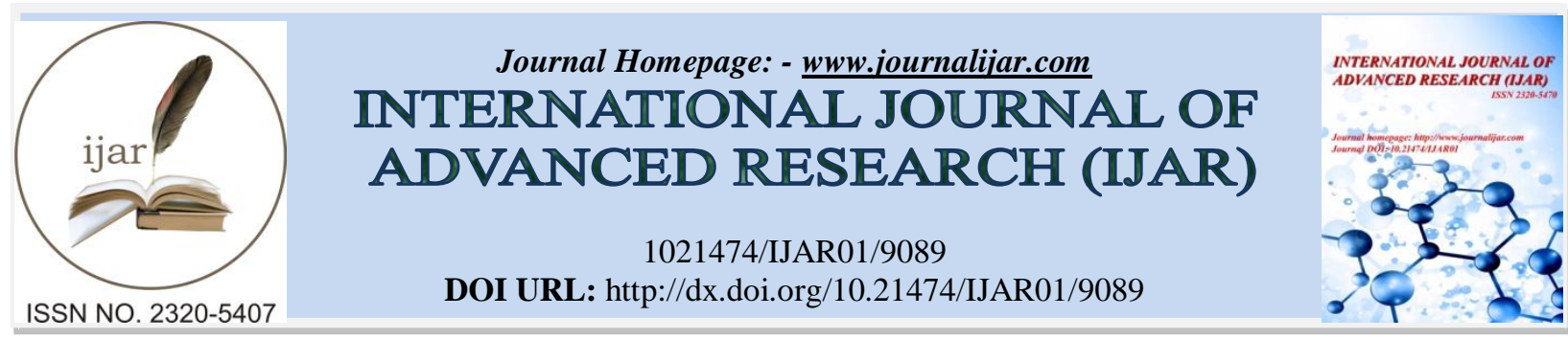

RESEARCH ARTICLE

\title{
THE EFFECT OF ACADEMIC LEADERSHIP AND ACADEMIC CULTURE ON THE COMMITMENT OF PROFESSIONAL LECTURERS IN NURSING VOCATIONAL SCHOOL.
}

\author{
Susi, Mukhneri Mukhtar And Matin. \\ Departement of Education Management - Universitas Negeri Jakarta, Jl. Rawamangun Muka, rt.11/rw.14, \\ Rawamangun, Pulo Gadung, Jakarta Timur, Daerah Khusus Ibukota Jakarta, Indonesia 13220.
}

\section{Manuscript Info}

\section{Manuscript History}

Received: 16 March 2019

Final Accepted: 18 April 2019

Published: May 2019

Keywords:-

academic leadership, academic culture, professional commitment

\section{Abstract}

The purpose of the research is to see the influence of academic leadership and academic culture on the professional commitment of lecturers in nursing vocational schools, the formulation of academic leadership and academic culture towards the professional commitment of lecturers is still a big problem in higher education. The method used in this quantitative research is to use survey research techniques, through the path analysis approach (Path Analysis). the results of the analysis and hypothesis testing indicate that the two hypotheses put forward in this study generally prove that each pathway has a positive direct effect. The conclusion in this study is that there is a direct positive influence from academic leadership and academic culture on the professional commitment of lecturers in vocational schools

Copy Right, IJAR, 2019,. All rights reserved.

\section{Introduction:-}

The development of science which gave birth to progress in the field of technology became one of the factors supporting the massive movement of globalization. These problems include 1) Leaders who lack the spirit of leadership and do not provide support in the quality of education. Quality improvement must begin with a university leader who is responsible for the provision of education in higher education, although, in essence, every college personnel has responsibility; 2) Lack of support from the foundation. In private universities, some foundations do not care about the quality of education. The foundation's orientation is only on quantity rather than quality which is of course oriented to large profits; 3) Academic culture that is still low such as interest in researching, writing Islamic articles, books causes the lecturers' knowledge to be less developed so that the process of knowledge transfer is minimal; 4) The professional commitment of lecturers is still low. A large number of lecturers who move home base causes disruption of learning so students are harmed which of course has an impact on academic quality; 5) Lack of infrastructure. The lack of infrastructure supporting academic facilities such as the library, laboratory, clinical practice area, etc. Infrastructure facilities are one of the supporters in the development of academic culture, increasing professional lecturers. Without the support of infrastructure facilities, it is difficult to get good academic quality. To create a good academic culture complete infrastructure is needed. 6) Managers who have long thought patterns, lack of concern for quality; The formulation of the problem in this study is the influence of academic leadership and academic culture on the professional commitment of lecturers in nursing vocational schools, the 
purpose of the research is to see the influence of academic leadership and academic culture on the professional commitment of lecturers in nursing vocational schools.

\section{A. Study of Theories and Methods: -}

Academic leadership has some similarities with leadership in general. In academic institutions, the stakeholders are students, society, industry and funding institutions. Stakeholders in academic institutions are more diverse so that academic leadership presents a different challenge to leadership in general. Milind Sathye (2004), explains Academic leadership is a special case of general leadership in as much as it refers to leadership in an academic setting or institutions. Academic institutions present a different setting than private or public sector organizations. Debowski dan Blake (2004) explains that academic leaders of teaching and learning require the general attributes noted as being important for many leadership roles - for example, the ability to develop a collaborative and supportive culture and to provide opportunities to share knowledge between colleagues. Richard Bolden etc (2012) explain the academic leadership as follows: Academic leadership as a process through which academic values and identities are constructed, promoted and maintained. This can be contrasted with a whole host of activities conducted within institutions, and the sector more widely, to organize and allocate academic tasks and processes, which could be more accurately described as academic management (Bolden et al., 2012, p. 42). Academic leadership as the skills to motivate others to take certain courses of action, to persuade others that prescribed tasks much be done on time and in a particular way, and to garner the respect of others, especially those with whom one works and/or associates (Learning, 2007, p. 29). The leadership needed in higher education is called academic leadership. Academic leaders must motivate, inspire, direct and lead faculty members towards achieving common goals (Siddique, Aslam, Khan, \& Fatima, 2011). The university's central and most distinctive activities - teaching, research, and public service - are carried out largely by its most distinctive sector of employees: the faculty. As a consequence, the decisions about how to allocate faculty effort are basic to the functioning of colleges and universities, and to their cost. ...most day-to-day decisions concerning these activities are entirely in the hands of departments and faculty members themselves ... (Dill, 2003, pp. 669-699). Davies, Douglas, \& Douglas (2007) find some aspects that have "cultural fit" or good cultural compatibility with the EFQM model and its supporters and cultural barriers to the application of the model. This research contributes to the understanding of academic culture and its effect on the application of quality improvement methodologies. The actions of top management also have a major impact on the organization's culture. Through words and behavior, senior executives establish norms that filter through the organization about, for instance, whether risk taking is desirable, how much freedom managers give employees, what is appropriate dress, and what actions earn pay raises, promotions, and other rewards ( $\mathrm{S}$. Robbins \& Judge, 2013, p. 520). leadership directly influences teacher commitment, and teacher commitment has a significant impact on retention. In particular, the practice of supportive leadership with a focus on emotional support has a positive impact on teacher commitment and retention (Gordon, 2018). Thibodeaux, Labat, Lee, \& Labat (2015) shows the relevance of the principal's leadership on the loyalty of a teacher to his profession. The most contributing factors for teachers to leave the profession are lack of administrative support, teacher workload, and student discipline. (1)the quality of teachers/trainers has a very serious impact on the assessment of quality in our universities; (2) instruction. the quality of instruction must be backed up with good teaching methods, adequate facilities to aid teaching and learning, equal learning opportunities for all students, provision of a conducive learning environment and communal assistance to students and teachers; (3)accreditation of programme; (4) inspection/monitoring; (5) evaluation: learner user surveys, internal and external appraisals, validation, moderation procedure, input process output for accessing quality, etc. (Idialu, 2013, pp. 432-433). The method used in this quantitative research is to use survey research techniques, through the path analysis approach (Path Analysis). This study will analyze the direct and indirect effects of one variable on another variable, which is called exogenous variables and endogenous variables.

\section{B. Results and Discussion:-}

The results of this study were conducted with descriptive statistical tests on each variable, namely academic leadership variables (X1), academic culture variables (X2), and professional commitment variables (Y) which included calculation of average, standard deviation, median variance, mode, minimum value, maximum value, range and frequency distribution accompanied by histograms. 
Descriptive statistics table for academic leadership variables (X1)

\begin{tabular}{clc}
\hline No. & \multicolumn{1}{c}{ Keterangan } & $\mathbf{X}_{\mathbf{1}}$ \\
\hline 1. & Mean & 114,70 \\
2. & Standard Error & 1,268 \\
3. & Median & 113,00 \\
4. & Mode & 140,00 \\
5. & Standard Deviation & 14,01 \\
6. & Sample Variance & 196,21 \\
7. & Range & 54 \\
8. & Minimum & 86 \\
9. & Maximum & 140 \\
10. & Sum & 13993 \\
11. & Count & 122 \\
\hline
\end{tabular}

Academic Leadership has a range of theoretical scores between 28 to 140, and the range of empirical scores between 86 and 140, so the range of scores is 54. The results of the calculation of data obtained an average of 114.70; the standard deviation of 14.01; variance of 196.21; median of 113.00; and the mode is 140.00. Furthermore, academic leadership data is presented in the form of frequency distribution as in the following table:

Academic Leadership distribution frequency table (X1)

\begin{tabular}{|c|c|c|c|c|c|c|c|}
\hline \multirow{2}{*}{ No } & \multirow{2}{*}{ Kelas } & \multirow{2}{*}{ Interval } & \multicolumn{2}{|c|}{ Batas } & \multicolumn{3}{|c|}{ Frekuensi } \\
\hline & & & Bawah & Atas & Absolut & Kumulatif & Relatif \\
\hline 1 & 86 & 92 & 85,5 & 92,5 & 8 & 8 & $6,56 \%$ \\
\hline 2 & 93 & 99 & 92,5 & 99,5 & 10 & 18 & $8,20 \%$ \\
\hline 3 & 100 & $-\quad 106$ & 99,5 & 106,5 & 15 & 33 & $12,30 \%$ \\
\hline 4 & 107 & 113 & 106,5 & 113,5 & $\begin{array}{r}3 \\
(0\end{array}$ & 63 & $24,59 \%$ \\
\hline 5 & 114 & 120 & 113,5 & 120,5 & 18 & 81 & $14,75 \%$ \\
\hline 6 & 121 & 127 & 120,5 & 127,5 & 18 & 99 & $14,75 \%$ \\
\hline 7 & 128 & 134 & 127,5 & 134,5 & 9 & 108 & $7,38 \%$ \\
\hline \multirow[t]{2}{*}{8} & 135 & 141 & 134,5 & 141,5 & 14 & 122 & $11,48 \%$ \\
\hline & & & & & 122 & & $100 \%$ \\
\hline
\end{tabular}

There are two axes needed in histogram making, namely the vertical axis as the absolute frequency axis, and the horizontal axis as the axis of the Academic leadership score. In this case, the horizontal axis is written at the interval of the interval class, ranging from 85.5 to 141.5 . These prices are obtained by subtracting the number 0.5 from the smallest data and adding a number 0.5 for each class limit at the highest limit. The frequency distribution of academic leadership variables (X1) above, obtained the highest frequency information in the interval class 107 - 113 as many as 30 respondents $(24.59 \%)$ and the lowest frequency in the interval class 86 - 92 as many as 8 eight respondents (6.56\%). The value of the academic leadership variable (X1) obtained from 122 respondents has been analyzed in the frequency distribution table above.

Descriptive statistics table of academic culture variables (X2)

\begin{tabular}{clc}
\hline No. & \multicolumn{1}{c}{ Keterangan } & $\mathbf{X}_{\mathbf{2}}$ \\
\hline 1. & Mean & 130,72 \\
2. & Standard Error & 1,356 \\
3. & Median & 129,50 \\
4. & Mode & 127,00 \\
5. & Standard Deviation & 14,98 \\
6. & Sample Variance & 224,37 \\
7. & Range & 71 \\
8. & Minimum & 89 \\
9. & Maximum & 160 \\
10. & Sum & 15948 \\
11. & Count & 122 \\
\hline
\end{tabular}

Academic Culture Data has a range of theoretical scores between 32 to 160, and an empirical score range of 89 to 160 , so that the score range is 71 . The results of the calculation of data obtained an average of 130.72; the standard deviation of 14.98; variance of 224.37; median of 129.50; and the mode is 127.00. Furthermore, the Academic Culture data is presented in the form of frequency distribution as in the table below. 
table for academic culture scores (X2)

\begin{tabular}{|c|c|c|c|c|c|c|c|}
\hline \multirow{2}{*}{ No } & \multirow{2}{*}{\multicolumn{2}{|c|}{ Kelas Interval }} & \multicolumn{2}{|c|}{ Batas } & \multicolumn{3}{|c|}{ Frekuensi } \\
\hline & & & Bawah & Atas & Absolut & Komulatif & Relatif \\
\hline 1 & 89 & -97 & 88,5 & 97,5 & 3 & 3 & $2,46 \%$ \\
\hline 2 & 98 & -106 & 97,5 & 106,5 & 3 & 6 & $2,46 \%$ \\
\hline 3 & 107 & -115 & 106,5 & 115,5 & 11 & 17 & $9,02 \%$ \\
\hline 4 & 116 & - 124 & 115,5 & 124,5 & 21 & 38 & $17,21 \%$ \\
\hline 5 & 125 & - 133 & 124,5 & 133,5 & 35 & 73 & $28,69 \%$ \\
\hline 6 & 134 & -142 & 133,5 & 142,5 & 22 & 95 & $18,03 \%$ \\
\hline 7 & 143 & $-\quad 151$ & 142,5 & 151,5 & 14 & 109 & $11,48 \%$ \\
\hline \multirow[t]{2}{*}{8} & 152 & $\begin{array}{l}-\quad 160 \\
\end{array}$ & 151,5 & 160,5 & 13 & 122 & $10,66 \%$ \\
\hline & & & & & 122 & & $100 \%$ \\
\hline
\end{tabular}

In this case, the horizontal axis is written at the interval of the class, starting from 88.5 to 160.5 . These prices are obtained by subtracting the number 0.5 from the smallest data and adding a number 0.5 for each class limit at the highest limit. The frequency distribution of the Academic Culture variable (X2) above, obtained the highest frequency information in the 125 - 133 interval class of 35 respondents $(28.69 \%)$ and the lowest frequency in the 89 - 97 and 98 - 106 interval classes as many as 3 respondents $(2.46 \%)$. The value of the Academic Culture variable (X2) obtained from 122 respondents has been analyzed in the frequency distribution table above.

Descriptive statistics table for professional commitment variables (Y)

\begin{tabular}{clc}
\hline No. & \multicolumn{1}{c}{ Keterangan } & $\mathbf{X}_{\mathbf{3}}$ \\
\hline 1. & Mean & 114,83 \\
2. & Standard Error & 1,157 \\
3. & Median & 114,00 \\
4. & Mode & 135,00 \\
5. & Standard Deviation & 12,78 \\
6. & Sample Variance & 163,40 \\
7. & Range & 50 \\
8. & Minimum & 85 \\
9. & Maximum & 135 \\
10. & Sum & 14009 \\
11. & Count & 122 \\
\hline
\end{tabular}

Professional commitment data has a theoretical score range of 27 to 135 , and an empirical score range of 85 to 135 , so that the score range is 50. The calculation results of the data obtained an average of 114.83; the standard deviation of 12.78; variance of 163.40; median of 114.00; and mode equal to 135.00. Furthermore, Professional Commitment data is presented in the form of frequency distribution as in the table below.

Frequency distribution table for professional commitment scores (Y)

\begin{tabular}{|c|c|c|c|c|c|c|c|}
\hline \multirow{2}{*}{ No } & \multirow{2}{*}{ Kelas } & \multirow{2}{*}{ Interval } & \multicolumn{2}{|c|}{ Batas } & \multicolumn{3}{|c|}{ Frekuensi } \\
\hline & & & Bawah & Atas & Absolut & Kumulatif & Relatif \\
\hline 1 & 85 & 91 & 84,5 & 91,5 & 4 & 4 & $3,28 \%$ \\
\hline 2 & 92 & 98 & 91,5 & 98,5 & 9 & 13 & $7,38 \%$ \\
\hline 3 & 99 & - 105 & 98,5 & 105,5 & 16 & 29 & $13,11 \%$ \\
\hline 4 & 106 & 112 & 105,5 & 112,5 & 28 & 57 & $22,95 \%$ \\
\hline 5 & 113 & $\begin{array}{ll}- & 119\end{array}$ & 112,5 & 119,5 & 16 & 73 & $13,11 \%$ \\
\hline 6 & 120 & 126 & 119,5 & 126,5 & 22 & 95 & $18,03 \%$ \\
\hline 7 & 127 & - 133 & 126,5 & 133,5 & 15 & 110 & $12,30 \%$ \\
\hline \multirow[t]{2}{*}{8} & 134 & 140 & 133,5 & 140,5 & 12 & 122 & $9,84 \%$ \\
\hline & & & & & 122 & & $100 \%$ \\
\hline
\end{tabular}

In this case, the horizontal axis is written at the interval of the interval class, starting from 84.5 to 140.5. These prices are obtained by subtracting the number 0.5 from the smallest data and adding a number 0.5 for each class limit at the highest limit.

The frequency distribution of the professional commitment variable (Y) above, obtained the highest frequency information in the 106 - 112 interval class as many as 28 respondents $(22.95 \%)$ and the lowest frequency in the 85 91 interval class of four respondents $(3.28 \%)$. The value of the Professional Commitment variable (Y) obtained from 122 respondents has been analyzed in the frequency distribution table above. 


\section{Test the significance and linearity of regression}

The results of the calculation of the significance test and linearity of the academic culture regression equation for academic leadership (X2 over X1) obtained the regression equation X2 $=37,393+0.814 \mathrm{X} 1$ and stated to be very significant. For the linearity test, the distribution of estimated points forms an acceptable linear line. The results of the calculation of the significance test and the linearity of the regression equation above professional commitment ( $\mathrm{Y}$ above $\mathrm{X} 1$ ) obtained the regression equation $\mathrm{Y}=42.606+0.630 \mathrm{X} 1$ and stated to be very significant. For the linearity test, the distribution of estimated points forms an acceptable linear line. The results of the calculation of the significance and linearity test, the regression equation professional commitment to academic culture (Y over X2) obtained the regression equation $\mathrm{Y}=31.517+0.637 \mathrm{X} 2$ and stated to be very significant. For the distribution linearity test, the estimated point forms an acceptable linear line.

Calculation of the correlation coefficient, path coefficient value, and test the significance of the path coefficient. The calculation results of the correlation coefficient X2 and X1 obtained $r=0.761$. The significance test of the correlation coefficients $\mathrm{X} 2$ and $\mathrm{X} 1$ obtained $\mathrm{t}$ count 12.847> t table 1.98, then the correlation coefficient is very significant. The results of the calculation of the $\mathrm{Y}$ and $\mathrm{X} 1$ correlation coefficients obtained $r=0.690$. Significance test of the correlation coefficient X3 and X1 obtained t count 10.44>t table 1.98, then the correlation coefficient is very significant. The calculation results of the $\mathrm{Y}$ and $\mathrm{X} 2$ correlation coefficients obtained $r=0.75$. Significance test of $\mathrm{Y}$ and $\mathrm{X} 2$ correlation coefficients obtained $\mathrm{t}$ count $12.31>\mathrm{t}$ table 1.98, then the correlation coefficient is very significant.

\section{Model testing}

Causal relationships between variables X2 and X1 variables obtained p21 path coefficient value of 0.761 and t count $=12.847$, with $\mathrm{t}$ table $(0.01: 120)=2.62$, so that $\mathrm{t}$ count $>\mathrm{t}$ table, reject $\mathrm{H} 0$, meaning that variable $\mathrm{X} 1$ has a positive direct effect on variable X2. Thus it is proven, that academic leadership has a positive direct effect on academic culture. Causal relationships between $\mathrm{Y}$ variables with $\mathrm{X} 1$ variables obtained by the path py1 coefficient value of 0.289 and $t$ count 3.208 , with $t$ table $(0.01: 119)=2.62$, so that tcount $>t$ table, reject $\mathrm{H} 0$, meaning that $\mathrm{X} 1$ variables have a positive direct effect on the variable Y. Thus it is proven, that academic leadership has a direct positive effect on Professional Commitment.

Causal relationships between $\mathrm{Y}$ variables with $\mathrm{X} 2$ variables obtained py2 path coefficient value of 0.527 and $\mathrm{t}$ count 5.844, with $\mathrm{t}$ table $(0.01: 119)=2.62$, so thitung $>\mathrm{t}$ table, reject $\mathrm{H} 0$, meaning that the variable $\mathrm{X} 2$ has a positive direct effect on the variable Y. Thus it is proven, that academic culture has a positive direct effect on professional commitment. Based on the results of the analysis of the influence of academic leadership (X1) on academic culture (X2). obtained $\rho 21$ path coefficient of 0.761 with $t$ count $=12.847$, while $t$ table $=1.98(\alpha=0.05 ; \mathrm{dk}=120)$. Because $t$ hitung $>t$ table, then $\mathrm{H} 0$ is rejected, $\mathrm{H} 1$ is accepted. Thus it can be concluded that academic leadership has a positive direct effect on academic culture. Based on the results of the path analysis of the influence of Academic Culture (X2) on professional commitment (X3) the path coefficient $\rho 32$ is obtained at 0.527 with $\mathrm{t}$ count $=5.844$, while the value of $\mathrm{t}$ table $=1.98(\alpha=0.05 ; \mathrm{dk}=119)$. Because $\mathrm{t}$ hitung $>\mathrm{t}$ table, then $\mathrm{H} 0$ is rejected, $\mathrm{H} 1$ is accepted. Thus it can be concluded that Academic Culture has a positive direct effect on professional commitment.

Based on the results of the path analysis of the influence of academic leadership (X1) on professional commitment (X3), the path coefficient $\rho 31$ is 0.289 with $t$ count $=3.208$, while the value of $t$ table $=1.98(\alpha=0.05$; $\mathrm{dk}=19)$. Because $t$ hitung $>t$ table, then $\mathrm{H} 0$ is rejected, $\mathrm{H} 1$ is accepted. Thus it can be concluded that academic leadership has a direct positive effect on professional commitment.

The results of the analysis and hypothesis testing indicate that the three hypotheses put forward in this study generally prove that each pathway has a positive direct effect. In detail, the discussion of the analysis and testing of the research hypothesis is described as follows:

The results of testing the first hypothesis can be concluded that there is a positive direct effect of academic leadership on academic culture with a correlation coefficient of 0.761 and a path coefficient of 0.761 . this gives the meaning of academic leadership a positive direct effect on academic culture. The results of the path indicator of academic leadership indicators on academic culture obtained the path coefficient $\rho_{21 \_}$for the third indicator of the academic leadership variable that is directing to have the most significant influence on the academic culture at 0.390. Stephen P. Robbins \& Timothy A. Judge (2013) state: The actions of top management also have a major impact on the organization's culture. Through words and behavior, senior executives establish norms that filter through the organization about, for instance, whether risk taking is desirable, how much freedom managers give employees, what is appropriate dress, and what actions earn pay raises, promotions, and other rewards (Robbins \& Judge, 2013, p. 520). Dill (2012) state Universities are culturally loaded organizations, in which values such as 
objectivity, academic freedom, and respect for students and human subjects guide academic behavior and are therefore reflected in the language, symbols, and ceremonies of academic life.

The results of testing the second hypothesis can be concluded that there is a positive direct effect of academic culture on professional commitment with a correlation coefficient of 0.747 and a path coefficient of 0.527 . this gives the meaning of academic culture a positive direct effect on professional commitment. Commitment to the profession is built on a conducive academic culture. The results of the path analysis of the academic culture indicator on professional commitment obtained the path coefficient value $\rho_{32_{5} 5}$ for the fifth indicator of the academic culture variable namely the scientific tradition has the most significant influence on the professional commitment of 0.246. Scientific tradition or academic tradition is a habit that is rooted and entrenched in both a person and a group of people with scientific activities that are built systematically, logically and supported by research. Scientific activities in this scientific tradition include reading, research, a publication of the results of research, scientific discussions. Every college academic community has scientific traditions and regulations in accordance with the characteristics of the academic community. The stronger the scientific tradition in a college, the more the need for additional academic regulations. This means that the scientific tradition is related to values, norms, and ethics that govern the attitudes and behavior of the academic community. Nasiima Sentrine (2011) in a dissertation study revealed that there was a positive and significant relationship between organizational culture and organizational commitment. This implies that the cultural dimension encourages employee participation, teamwork, freedom in carrying out organizational activities causing organizational commitment within employees. This commitment is exemplified by the desire of employees to spend most of their careers in organizations, believe in missions, institutional values and feel part of the Institution (Sentrine, 2011, pp. 1-63). S. Setyaningsih (2017) quantitative study showed that the professional commitment of lecturers was influenced by variables of empowerment, academic culture, and trust. The variables of empowerment, academic culture, and trust have a positive direct impact on lecturers 'professional commitment of $67.4 \%$, and the remaining $32.6 \%$ are influenced by other variables not used in this study, such as career development for lecturers and lecturers' performance appraisal systems (Setyaningsih, 2017, pp. 1-9).

The results of testing the third hypothesis can be concluded that there is a positive direct effect of academic leadership on professional commitment with a correlation coefficient of 0.690 and a path coefficient of 0.289 . this gives the meaning of academic leadership a positive direct effect on professional commitment. The results of the path analysis of academic leadership indicators towards professional commitment obtained the path coefficient value $\rho_{31 \_}$for the fourth indicator of the academic leadership variable that is facilitating has the most significant influence on the professional commitment of 0.286. Facilitative leadership will always involve followers as much as possible in the formation of vision and mission, and build a cohesive team with policies that are oriented towards improving academic quality. Basically, facilitative leaders help others learn how to learn. Leaders themselves must also have the willingness and ability to facilitate subordinates through policies that are oriented towards improving academic quality.

Smith (2003) describes facilitative leadership is a people-centered, quality and results driven process of developing and supporting culture in the workplace that facilitates goal achievement through effective relational processes. Facilitative leadership is particularly important to the effective group process, teamwork, workplace culture and change management in the workplace" (Smith, 2003). Siebens (2011) states facilitating leadership aims to engage as many people as possible with decision-making processes. So, the number of actively engaged co-workers indicates the level of facilitation by the leader. To enable all co-workers to be engaged in the decision making processes in an effective and efficient way, they have to be informed accurately. Therefore the gathering and the internal dissemination of data is an indicator for Facilitating leadership (Siebens, 2011, p. 87).

\section{Conclusion:-}

The conclusions in this study are: First, there is a positive direct influence of leadership on academic culture with indicators directing the most significant influence on academic culture. This means that leaders who always give direction to lecturers in improving, scientific development and profession will improve academic culture.

Second, there is a positive direct effect of academic culture on professional commitment with indicators of scientific tradition that have the most significant influence on professional commitment. This means that by increasing the scientific tradition on academic activities, lecturers can increase the professional commitment of lecturers. Third, there is a positive direct effect of academic leadership on professional commitment with facilitating indicators giving the most significant influence on professional commitment. This means that leaders who always facilitate lecturers in every academic activity can increase the professional commitment of lecturers. 


\section{Bibliography:-}

1. Bolden, R., Gosling, J., O'Brien, A., Peters, K., Ryan, M., \& Haslam, A. (2012). Research and Development Series. Academic Leadership: Changing Conceptions, Identities and Experiences in UK Higher Education (Vol. 3). London.

2. Colquitt, J. A., LePine, J. A., \& Wesson, M. J. (2017). Organizational Behavior-Improving Performance and Commitment in The Workplace. New York: McGraw-Hill Education.

3. Comas-Forgas, R., \& Sureda-Negre, J. (2010). Academic Plagiarism: Explanatory Factors from the Students' Perspective. Journal of Academic Ethics, 8(3), 217-232. https://doi.org/10.1007/s10805-010-9121-0

4. Davies, J., Douglas, A., \& Douglas, J. (2007). The effect of academic culture on the implementation of the EFQM Excellence Model in UK universities. Quality Assurance in Education. https://doi.org/10.1108/09684880710829965

5. Dill, D. D. (2003). An Institutional Perspective on Higher Education Policy: The Case of Academic Quality Assurance. Higher Education: Handbook of Theory and Research SE - 12 (Vol. 18). Dordrecht, The Netherlands: The University of North Carolina of Chapel Hill. https://doi.org/10.1007/978-94-010-0137-3_12

6. Gordon, S. D. (2018). Leadership's Role in Teachers' Commitment and Retention: a Case Study Analysis. Proquest LL. Delaware State University.

7. Idialu, E. E. (2013). Ensuring Quality Assurance In Vocational Education. Contemporary Issues In Education Research - Fourth Quarter 2013, 6(4), 431-438. https://doi.org/10.1177/019263656504930113

8. Jacobson, S. (2011). Leadership effects on student achievement and sustained school success. International Journal of Educational Management. https://doi.org/10.1108/09513541111100107

9. Learning, D. R. (2007). Academic Leadership: A Practical Guide to Chairing the Department (2nd ed.). Colorado: Bolton, Mass. : Anker Pub. Co.

10. Robbins, S., \& Judge, T. A. (2013). Organizational Behavior 15th ed. Zhurnal Eksperimental'noi $i$ Teoreticheskoi Fiziki. https://doi.org/10.12737/4477

11. Sentrine, N. (2011). Organisational Culture, Leader-Member Exchange, Organisational Commitment And Quality Education: The Case Of Public Universities in Uganda. Makerere University.

12. Setyaningsih, S. (2017). Causal relationship model between variables using linear regression to improve professional commitment of lecturer Causal relationship model between variables using linear regression to improve professional commitment of lecturer. In IOP Conference Series: Materials Science and Engineering. https://doi.org/10.1088/1742-6596/755/1/011001

13. Siddique, A., Aslam, H. D., Khan, M., \& Fatima, U. (2011). Impact of Academic Leadership on Faculty's Motivation and Organizational Effectiveness in Higher Education. International Journal Of Academic Research, 3(3), 730-737.

14. Siebens, H. (2011). Facilitating leadership. In Leading With Wisdom (pp. 77-94). Antwerp: Garant.

15. Smith, A. (2003). Facilitative Leadership. Retrieved January 26, 2019, from https://www.grad.ubc.ca/currentstudents/professional-development/facilitative-leadership. 
